Finanse, Rynki Finansowe, Ubezpieczenia nr 3/2017 (87), cz. 1

\title{
Funkcje doradcze audytu wewnętrznego w policji w zakresie zabezpieczenie finału regat The Tall Ship Races 2017
}

\author{
Marek Jasztal
}

\begin{abstract}
Streszczenie: $\mathrm{Cel}$ - Wdrożenie czynności doradczych audytu wewnętrznego w obszarze przygotowań policji do zabezpieczenia finału regat The Tall Ships Races 2017.

Metodologia badania - Zastosowano metodę mapy ryzyka w audycie wewnętrznym dla identyfikacji potrzeb i diagnozowania ryzyka na bazie zebranych danych od kadry kierowniczej oraz wyznaczonych do zabezpieczenia uczestników wydarzeń specjalnych.

Wynik - Na podstawie analizy przeprowadzonej z wykorzystaniem mapy ryzyka uzyskano informację o potencjalnych rodzajach ryzyka i ich wpływie na organizację zabezpieczenia imprezy masowej. Ponadto zaprezentowano kierunki rekomendacji czynności doradczych.

Oryginalność/wartość - Materiał badawczy pozwolił na obiektywne i niezależne zapoznanie się z zagadnieniem oraz wyciągnięcie merytorycznych wniosków dotyczących wdrożenia czynności doradczych.
\end{abstract}

Slowa kluczowe: audyt wewnętrzny, czynności doradcze, ryzyko, impreza masowa

\section{Wprowadzenie}

Wykonywanie zadań ustawowych policji koncentruje się na zapewnieniu bezpieczeństwa publicznego. Realizacji powyższej tezy są podporządkowane zadania policji wynikające z art. 1 Ustawy z 6 kwietnia 1990 roku o Policji (Dz.U. z 2011 r., nr 287, poz. 1687 z późn. zm.) oraz wydanych na jej podstawie aktów prawnych wykonawczych, zarówno powszechnie obowiązujących, jak i wewnętrznych. Zapewnienie bezpieczeństwa publicznego należy rozumieć jako ogół działań wdrażanych przez państwo i obywateli, w wyniku których można czuć się bezpiecznie. Potrzeby bezpieczeństwa dotyczą spokoju, wolności od strachu i zależności. Pobudzają do działania, zapewniając nienaruszalność. Ujawniają się, gdy dotychczasowe nawyki okazują się mało przydatne. Potrzeby podstawowe, dotyczące spraw fizjologicznych oraz bezpieczeństwa, gdy nie są zaspokojone, dominują nad wszystkimi innymi potrzebami, wypierają je na dalszy plan i decydują o zmiennych i złożonych zachowaniach człowieka.

\footnotetext{
* mgr Marek Jasztal, Komenda Wojewódzka Policji w Szczecinie, Zastępca Komendanta Wojewódzkiego Policji w Szczecinie, e-mail: jasztal@op.pl.
} 
Wdrożenie przez policję działań dotyczących zapewnienia bezpieczeństwa ma szczególne znacznie podczas imprez masowych. Największą imprezą masową w 2017 roku był odbywający się w okresie 5-8 sierpnia 2017 roku w Szczecinie finał regat The Tall Ships Races 2017.

Jednym $\mathrm{z}$ elementów przygotowań do zabezpieczenia finału był realizowany $\mathrm{w}$ formie czynności doradczych audytu wewnętrznego przegląd stanu przygotowania i planowanego zabezpieczenia działań przez zachodniopomorską policję.

\section{Zabezpieczenie finalu regat The Tall Ships Races 2017}

Szczególnie istotna jest potrzeba bezpieczeństwa. Bezpieczeństwo to stan bądź proces, gwarantujący istnienie podmiotu oraz możliwość jego rozwoju. Daje poczucie pewności, gwarancje zachowania i szanse na doskonalenie istnienia, czyli jednej z podstawowych potrzeb człowieka. Odznacza się brakiem ryzyka utraty czegoś szczególnie cennego - życia, zdrowia, pracy, szacunku, uczuć, dóbr materialnych i dóbr niematerialnych. Bezpieczeństwo jest naczelną potrzebą człowieka i grup społecznych, jest także podstawową potrzebą państw i systemów międzynarodowych; jego brak wywołuje niepokój i poczucie zagrożenia. Człowiek, grupa społeczna, państwo, organizacja międzynarodowa starają się oddziaływać na swoje otoczenie zewnętrzne i sferę wewnętrzną, by usuwać a przynajmniej oddalać zagrożenia, eliminując własny lęk, obawy, niepokój i niepewność. Zagrożenia mogą być skierowane na zewnątrz i do wewnątrz; tak samo powinny być skierowane działania w celu ich likwidowania ${ }^{1}$.

Dążenie do zapewnienia wdrożenia wymaganych działań w obszarze bezpieczeństwa publicznego generuje konieczność określenia zakresu przedmiotowego i podmiotowego wymaganych działań. Zakres przedmiotowy powinien dotyczyć działań przeprowadzanych przez jednostki i komórki organizacyjne policji, których prawidłowość działania wpływa na prawidłowość i bezpieczeństwo zabezpieczenia największej imprezy plenerowej i żeglarskiej The Tall Ship Races 2017 m.in. w zakresie zapewnienia bezpieczeństwa na trasach dojazdowych, kolejowych, dworcach, a także uczestnikom regat i osobom przebywającym i zamieszkującym w Szczecinie.

Zakres podmiotowy należy rozumieć jako koordynację realizowaną przez Sztab Policji KWP w Szczecinie i Komendę Miejską Policji w Szczecinie oraz inne komórki organizacyjne funkcjonujące $\mathrm{w}$ ramach powołanego przez Komendanta Wojewódzkiego Policji w Szczecinie zespołu koordynującego do spraw przygotowania zachodniopomorskiej policji do zabezpieczenia finału regat The Tall Ships Races 2017.

Przygotowanie zabezpieczenia finału regat The Tall Ships Races 2017 wymaga zapewnienia legalności działania w obszarze przygotowań. Legalność zabezpieczenia powinna być weryfikowana przez pryzmat działań w obszarze następujących aktów prawnych:

\footnotetext{
${ }^{1}$ http://pl.wikipedia.org.
} 
a) powszechnie obowiązujących:

- Ustawy z dnia 6 kwietnia 1990 roku o Policji (Dz.U. z 2015 r., poz. 355 i 529),

- Uchwały nr 2/2017 Międzyresortowego Zespołu Zagrożeń Terrorystycznych z dnia 11 maja 2017 roku o przyjęciu uzgodnienia zakresu współdziałania w sprawach sporządzania dokumentacji dotyczącej przygotowania do zabezpieczenia antyterrorystycznego istotnych spotkań i konferencji o charakterze międzynarodowym oraz imprez masowych, która weszła w życie z dniem 1 czerwca 2017 roku;

b) uregulowań wewnętrznych w policji:

- Decyzji nr 15/17 Komendanta Wojewódzkiego Policji w Szczecinie z dnia 19 stycznia 2017 roku w sprawie powołania zespołu koordynującego do spraw przygotowania zachodniopomorskiej Policji do zabezpieczenia finału regat The Tall Ship Races 2017,

- Decyzji nr 150/17 Komendanta Wojewódzkiego Policji w Szczecinie z dnia 20 czerwca 2017 roku w sprawie zarządzenia operacji policyjnej o kryptonimie „Regaty 2017” oraz utworzenia struktury dowodzenia i powołania Sztabu Dowódcy Operacji Policyjnej,

- Decyzji nr 15/2017 Komendanta Miejskiego Policji w Szczecinie z dnia 30 stycznia 2017 roku w sprawie powołania zespołu do spraw przygotowania koncepcji zapewnienia bezpieczeństwa i porządku publicznego podczas finału regat The Tall Ship Races 2017 na terenie miasta Szczecin,

- Decyzji nr 310 Komendanta Głównego Policji z dnia 28 sierpnia 2014 roku w sprawie prowadzenia rozliczeń finansowych związanych z kierowaniem policjantów do działań w ramach operacji policyjnych,

- Decyzji nr 262 Komendanta Głównego Policji z dnia 6 sierpnia 2015 roku zmieniająca decyzję w sprawie prowadzenia rozliczeń finansowych związanych z kierowaniem policjantów do działań w ramach operacji policyjnych,

- regulaminu organizacyjnego Komendy Wojewódzkiej Policji w Szczecinie,

- Zarządzenia nr 23 KGP z dnia 24 września 2014 roku w sprawie metod i form przygotowania i realizacji działań policji w związku ze zdarzeniami kryzysowymi (Dz. Urz. KGP, poz. 65 z późn. zm.),

- Zarządzenia nr 982 KGP z dnia 21 września 2007 roku w sprawie zasad organizacji i trybu wykonywania przez policję zadań związanych z rozpoznaniem, zapobieganiem, zwalczaniem przestępstw i wykroczeń popełnionych w związku z imprezami sportowymi oraz gromadzenia i przetwarzania informacji dotyczących bezpieczeństwa masowych imprez sportowych (Dz. Urz. KGP, nr 17, poz. 129),

- Zarządzenia nr 3 KGP z dnia 27 lutego 2015 roku w sprawie prowadzenia Policyjnego Rejestru Imprez Masowych (Dz. Urz. KGP, poz. 14). 


\section{Rola audytu wewnętrznego $w$ zabezpieczeniu finału regat The Tall Ships Races 2017}

Obecnie w Polsce audyt wewnętrzny jest rozumiany przez pryzmat definicji podanej przez The Institute of Internal Auditors. Jest niezależną działalnością doradczą i weryfikującą, której celem jest usprawnienie operacyjne organizacji i wniesienie do niej wartości dodanej².

Usługi doradcze audytu są najczęściej wykonywane na konkretne zlecenie kierownika jednostki. Powinny być z nim szczegółowo określone co do zakresu i charakteru. Mają pomóc w identyfikacji ekspozycji ryzyka i podjęciu decyzji na poziomie kierowniczym w zakresie sposobu i formy jego ograniczenia.

Działania o charakterze doradczym obejmują w szczególności ocenę planowanych czynności, projektowanych systemów, procedur i rozwiązań, opiniowanie projektów aktów wewnętrznych oraz składanie wniosków i mają na celu usprawnienie funkcjonowania jednostki. Mogą one być wykonywane, jeżeli ich charakter nie narusza obiektywizmu i niezależności audytora wewnętrznego oraz nie prowadzi do przejęcia przez niego odpowiedzialności kierownictwa jednostki. Audytorzy wewnętrzni obserwują fakty, wyciągają z nich wnioski i rekomendują usprawnienia (Winiarska, 2005, s. 40).

W ramach prowadzenia czynności doradczych audytu audytorowi wewnętrznemu przysługują następujące uprawnienia:

a) prawo wglądu do wszelkich informacji, danych, dokumentów i innych materiałów związanych z funkcjonowaniem danego obszaru jednostki, w tym zawartych na elektronicznych nośnikach informacji, a także do wykonywania z nich kopii, odpisów, wyciągów, zestawień lub wydruków, z zachowaniem przepisów w zakresie tajemnic;

b) prawo żądania od pracowników jednostki potwierdzenia kopii, odpisów, wyciągów lub wydruków, o których mowa w pkt a);

c) zagwarantowane prawo dostępu do pomieszczeń jednostki, z zachowaniem przepisów o tajemnicach;

d) prawo uzyskiwania od kierownika i pracowników audytowanej komórki informacji oraz wyjaśnienia w celu zapewnienia efektywnego i wydajnego przeprowadzania czynności doradczych;

e) uprawnienie do czynności doradczych we wszystkich obszarach działalności jednostki.

\section{Wdrożenie czynności doradczych}

W celu zapewnienia przygotowania policji do działan podejmowanych dla prawidłowego zabezpieczenia imprezy The Tall Ship Races 2017 oraz osiągnięcia podstawowego celu, tj. ochrony życia i zdrowia ludzi i mienia przed bezprawnymi zamachami naruszającymi te

\footnotetext{
${ }^{2}$ https://na.theiia.org/Pages/IIAHome.aspx.
} 
dobra, a także ochrony bezpieczeństwa i porządku publicznego bardzo ważna jest identyfikacja i ocena ryzyka poszczególnych wydarzeń w ramach operacji zabezpieczenia imprezy. Właściwie przygotowana i przeprowadzona analiza ryzyka wskazuje elementy, które zagrażają bezpieczeństwu wydarzenia i jego uczestnikom, a dzięki sformułowanym wnioskom pozwala na prawidłową reakcję i niedopuszczenie do sytuacji niepożądanej lub minimalizację jej skutków.

Analiza ryzyka zabezpieczenia finału regat obejmuje komórki organizacyjne służb prewencyjnych, kryminalnych i logistycznych Komendy Wojewódzkiej Policji w Szczecinie, Komendy Miejskiej w Szczecinie, Zarządu Centralnego Biura Śledczego Policji oraz innych jednostek organizacyjnych policji w Polsce i z Niemiec - Landu Meklemburgii i Brandenburgii, kierujących siły i środki wsparcia dla zabezpieczenia wydarzenia.

Przeprowadzona przez audytora wewnętrznego analiza ryzyka z wykorzystaniem metody mapy ryzyka identyfikuje ryzyko, co zaprezentowano w tabeli 1.

\section{Tabela 1}

Ocena ryzyka zabezpieczenia imprezy masowej w Policji

\begin{tabular}{|c|c|c|c|}
\hline & Analiza ryzyka & & \\
\hline Ryzyko & opis ryzyka & znaczenie & wpływ \\
\hline 1 & 2 & 3 & 4 \\
\hline Terrorystyczne & $\begin{array}{l}\text { potrzeba zabezpieczenia odpowiednich sił i środków } \\
\text { ukierunkowanych na zagrożenia związane z zamachami } \\
\text { terrorystycznymi przy przeprowadzaniu dużej imprezy - } \\
\text { The Tall Ships Races } 2017 \text { - nie biletowanej na dużym } \\
\text { obszarze; brak analizy zamachów terrorystycznych, które } \\
\text { wystąpiły na terenie Europy }\end{array}$ & 9 & 6 \\
\hline Prawne & $\begin{array}{l}\text { konieczność modyfikacji działań zgodnych z aktualnie } \\
\text { obowiązującymi wewnętrznymi aktami KWP oraz przepisami } \\
\text { prawa powszechnie obowiązującymi w zakresie realizacji } \\
\text { czynności dotyczaccych koordynowania, zabezpieczenia, } \\
\text { rozpoznania operacyjnego oraz wsparcia realizowanych zadań }\end{array}$ & 3 & 4 \\
\hline Analityczne & $\begin{array}{l}\text { potrzeba przygotowania analizy oraz wyciągania wniosków } \\
\text { w zakresie przetworzenia i interpretacji danych o operacjach } \\
\text { zabezpieczenia imprezy The Tall Ships Races z lat ubiegłych: } \\
2007 \text { i } 2013 \text { oraz innych imprez o podobnych operacjach }\end{array}$ & 8 & 6 \\
\hline Operacyjne & $\begin{array}{l}\text { wykonywanie rozpoznania w zakresie dostarczania informacji } \\
\text { o miejscach grupowania „pseudouczestników” imprezy, } \\
\text { bieżących informacji o rozwoju sytuacji w miejscach } \\
\text { rzeczywistych zabezpieczeń oraz we wrażliwych punktach } \\
\text { miasta }\end{array}$ & 8 & 7 \\
\hline Kadrowe & $\begin{array}{l}\text { konieczność zapełnienia wakatów w służbie prewencyjnej, } \\
\text { kryminalnej i wspomagającej lub zapełnienie wakatów } \\
\text { policjantami, których przydatność fizyczna w zakresie } \\
\text { zabezpieczenia dużych imprez jest ograniczona (np. drobne } \\
\text { kobiety); brak identyfikacji z jednostką, zanikająca tradycja } \\
\text { przekazywania doświadczeń policyjnych przez długoletnich } \\
\text { pracowników nowo zatrudnionym policjantom }\end{array}$ & 6 & 4 \\
\hline
\end{tabular}




\begin{tabular}{|c|c|c|c|}
\hline 1 & 2 & 3 & 4 \\
\hline Szkoleniowe & $\begin{array}{l}\text { realizacja szkoleń funkcjonariuszy w zakresie stosowania } \\
\text { zgodnych z obowiązującymi procedurami zachowań, } \\
\text { formowania niezbędnych w określonych sytuacjach szyków, } \\
\text { ćwiczeń w przypadku działań zwartych, szkoleń policjantów } \\
\text { związanych z odpornością psychologiczną a także stosowania } \\
\text { przewagi psychologicznej w przypadku wystąpienia zdarzeń } \\
\text { z „pseudouczestnikami” imprezy The Tall Ships Races }\end{array}$ & 6 & 3 \\
\hline $\begin{array}{l}\text { Funkcjonowania } \\
\text { systemu zastępstw }\end{array}$ & $\begin{array}{l}\text { zapewnienie możliwości wykonania w wymaganym czasie } \\
\text { niezbędnej czynności z powodu nieobecności pracownika } \\
\text { oraz nieprzeszkolenia osoby zastępującej; zaangażowanie sił } \\
\text { Garnizonu Zachodniopomorskiego do zabezpieczenia innych } \\
\text { imprez masowych sportowych oraz artystyczno-rozrywkowych } \\
\text { odbywających się w tym samym czasie (w sierpniu } 2017 \text { r.) }\end{array}$ & 5 & 3 \\
\hline Techniczne & $\begin{array}{l}\text { możliwe nieprawidłowości w funkcjonowaniu zasobów } \\
\text { sprzętowych (pojazdy, sprzęt łączności, uzbrojenie) } \\
\text { niezbędnych do prawidłowego wykonywania zadań; brak } \\
\text { dostosowania sprzętu (kamizelek, ochraniaczy, zestawów } \\
\text { hełmowych) do warunków ergonomii i swobody działania; } \\
\text { brak umiejscowienia odpowiedniej ilości systemów łączności }\end{array}$ & 3 & 5 \\
\hline Nadzorcze & $\begin{array}{l}\text { funkcjonowanie procedur w zakresie powierzania zadań, } \\
\text { uprawnień i odpowiedzialności dotyczących wykonywania } \\
\text { funkcji dowodzenia, koordynacji i nadzoru na poszczególnych } \\
\text { szczeblach i poziomach zarządzania operacją „,Regaty } \\
2017 \text { ”; brak bieżącego reagowania w przypadku pojawienia } \\
\text { się sytuacji nadzwyczajnych; niewykonywanie czynności } \\
\text { wsparcia w przypadku pojawienia się ewentualnych przeszkód } \\
\text { i problemów }\end{array}$ & 5 & 4 \\
\hline Finansowe & $\begin{array}{l}\text { pojawienie się określonych kosztów dla KWP w Szczecinie } \\
\text { lub innych jednostek policji w związku z procesami sądowymi } \\
\text { związanymi z zachowaniem policjantów oraz szkodami } \\
\text { w sprzęcie policyjnym oraz osób trzecich powstałymi } \\
\text { w związku z właściwym lub niewłaściwym wykonywaniem } \\
\text { czynności służbowych }\end{array}$ & 4 & 4 \\
\hline Informacyjne & $\begin{array}{l}\text { pojawiające się nieprawidłowości w procesie przepływu } \\
\text { informacji wewnętrznej oraz zewnętrznej, przekazywanie } \\
\text { nierzetelnych, nieprawdziwych informacji; powstanie } \\
\text { niekontrolowanego wypływu informacji, który ma negatywny } \\
\text { wpływ na opinię publiczną w zakresie realizacji zadań policji; } \\
\text { brak koordynacji systemów łączności }\end{array}$ & 6 & 6 \\
\hline $\begin{array}{l}\text { Współpracy } \\
\text { zewnętrznej }\end{array}$ & $\begin{array}{l}\text { bieżąca współpraca z organami sądowymi i prokuratorskimi } \\
\text { - przepływ informacji, opóźnienia czasowe; brak } \\
\text { kompatybilności sprzętu wykorzystywanego przez policję oraz } \\
\text { inne służby uczestniczące w czynnościach prewencyjnych } \\
\text { (np. SG, SM, pogotowie ratunkowe); brak efektywnej formy } \\
\text { współpracy i wsparcia niemieckiej policji Landu Meklemburgii } \\
\text { i Branderburgii }\end{array}$ & 6 & 7 \\
\hline
\end{tabular}

Źródło: M. Badach KWP w Szczecinie. 


\section{Tabela 2}

Ujęcie zdefiniowanego ryzyka na mapie ryzyka

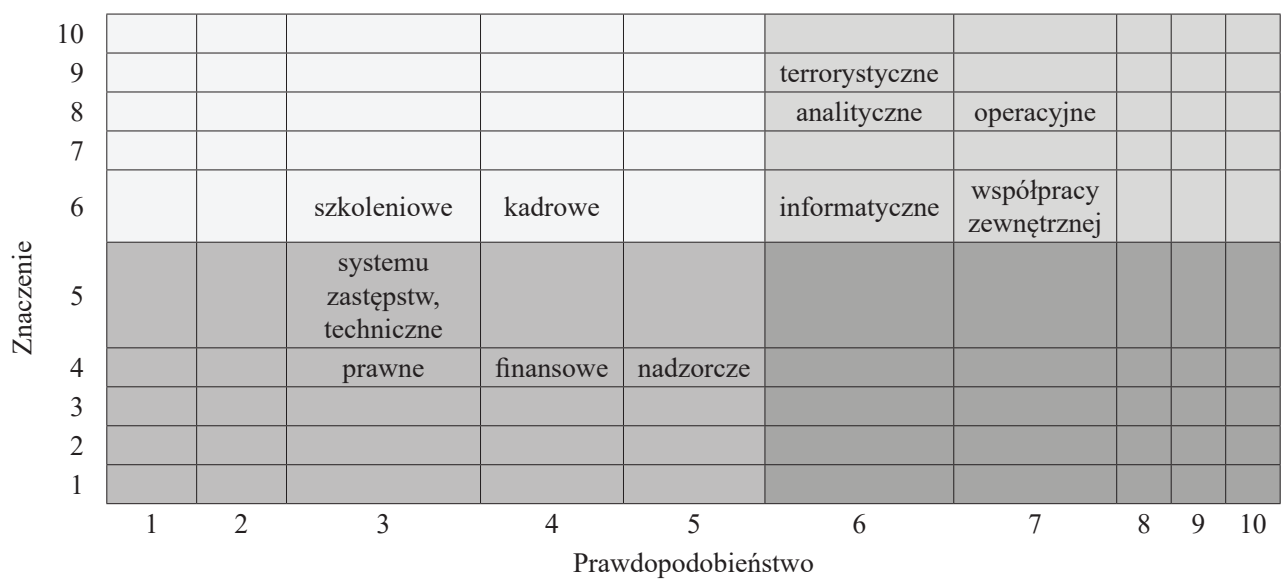

Źródło: opracowanie własne na podstawie sprawozdania M. Badach KWP w Szczecinie.

Na podstawie analizy ryzyka, audytor wewnętrzny dokonuje ukierunkowania zakresu i szczegółowości czynności doradczych. Metodyczne ujęcie ryzyka oraz rekomendacji z czynności doradczych przedstawiono w tabeli 3.

\section{Tabela 3}

Ujęcie proponowanych odpowiedzi na ryzyko

\begin{tabular}{|c|c|c|c|}
\hline $\begin{array}{l}\text { Kwadrat } \\
\text { ryzyka }\end{array}$ & Ryzyko & $\begin{array}{l}\text { Odpowiedź na ryzyko - rekomendacje wynikające } \\
\text { z czynności doradczych }\end{array}$ & Uwagi \\
\hline 1 & 2 & 3 & 4 \\
\hline \multirow[t]{3}{*}{$\begin{array}{l}\text { Kwadrat I } \\
\text { Zapobiegaj } \\
\text { u źródla }\end{array}$} & analityczne & $\begin{array}{l}\text { należy powołać zespół ds. przygotowania } \\
\text { zachodniopomorskiej policji do zabezpieczenia finału regat } \\
\text { oraz dokonać wprowadzona koordynacji wymiany informacji } \\
\text { pomiędzy komórkami i jednostkami organizacyjnymi; } \\
\text { należy dokonać analizy zdarzeń generujących ryzyko, które } \\
\text { wystąpiły w dwóch poprzednich edycjach finału Regat } \\
\text { w } 2007 \text { i } 2013 \text { r. oraz wyciągnąć wnioski }\end{array}$ & \\
\hline & operacyjne & $\begin{array}{l}\text { należy zwiększyć zakres wykorzystania nowoczesnych } \\
\text { narzędzi informatycznych pozwalających na dostęp do } \\
\text { informacji, szczególnie w zakresie możliwych działań } \\
\text { grup zakłócających porządek publiczny; dokonać } \\
\text { zwiększenia zaangażowania służb kryminalnych w działania } \\
\text { wywiadowcze; zalecane jest wprowadzenie nowoczesnego, } \\
\text { zintegrowanego systemu przekazu informacji gwarantującego } \\
\text { bezpieczeństwo służby }\end{array}$ & \\
\hline & $\begin{array}{l}\text { współpracy } \\
\text { zewnętrznej }\end{array}$ & $\begin{array}{l}\text { rekomenduje się wdrożenie zintegrowanego systemu } \\
\text { łączności dla służb zabezpieczających i ratunkowych, } \\
\text { ustalenia szczegółowych procedur w zakresie wymiany } \\
\text { informacji pomiędzy organami }\end{array}$ & \\
\hline
\end{tabular}




\begin{tabular}{|c|c|c|}
\hline \multirow[t]{3}{*}{1} & 2 & 3 \\
\hline & terrorystyczne & $\begin{array}{l}\text { należy dokonać zabezpieczenia odpowiednich sił i środków } \\
\text { ukierunkowanych na zagrożenia związane z zamachami } \\
\text { terrorystycznymi }\end{array}$ \\
\hline & informacyjne & $\begin{array}{l}\text { zalecane jest przeprowadzenie weryfikacji w zakresie } \\
\text { bezpieczeństwa przepływu informacji, w związku ze } \\
\text { zdarzeniami przeszłymi, m.in. finału regat w } 2007 \text { i } 2013 \text { r.; } \\
\text { należy zwiększyć ochronę informacji operacyjnej i bieżącej } \\
\text { w toku realizacji czynności zabezpieczenia i przywracania } \\
\text { porządku publicznego }\end{array}$ \\
\hline \multirow[t]{2}{*}{$\begin{array}{l}\text { Kwadrat II } \\
\text { Wykryj } \\
\text { i monitoruj }\end{array}$} & kadrowe & $\begin{array}{l}\text { rekomenduje się dokonane wewnętrzne przeniesienia w celu } \\
\text { efektywności służby; należy dokonać zapewnienia służby } \\
\text { o specjalistycznych kwalifikacjach, np. policjanci z patentami } \\
\text { motorzysty/sternika motorowodnego, uprawnienia ratownika } \\
\text { medycznego, policjanci ze znajomością języków obcych } \\
\text { w stopniu komunikatywnym (w celu komunikowania } \\
\text { się w razie potrzeby z uczestnikami imprezy innych } \\
\text { narodowości), policjanci realizujący zadania z nieletnimi } \\
\text { (stanowiska ds. nieletnich, patologii, itp.); w czasie } \\
\text { finału regat i imprez towarzyszących należy wprowadzić } \\
\text { ograniczenia w udzielaniu urlopów wypoczynkowych }\end{array}$ \\
\hline & szkoleniowe & $\begin{array}{l}\text { należy dokonać przeszkolenia szkolenia personelu, np. } \\
\text { z zakresu obsługi paralizatorów, wzmacniania odporności } \\
\text { psychicznej policjantów realizujących zabezpieczenie finału } \\
\text { regat }\end{array}$ \\
\hline $\begin{array}{l}\text { Kwadrat III } \\
\text { Monitoruj }\end{array}$ & & brak ryzyka w III kwadracie - Monitoruj \\
\hline \multirow[t]{5}{*}{$\begin{array}{l}\text { Kwadrat IV } \\
\text { Minimalna } \\
\text { kontrola }\end{array}$} & finansowe & $\begin{array}{l}\text { zaleca się dokonanie weryfikacji przez k.o. kosztów ex ante, } \\
\text { związanych z zakwaterowaniem, wyżywieniem, dokonanymi } \\
\text { zakupami, tj. uzbrojeniem, kamizelki, technika policyjna itp. }\end{array}$ \\
\hline & $\begin{array}{l}\text { funkcjonowanie } \\
\text { systemu zastępstw }\end{array}$ & $\begin{array}{l}\text { należy dokonać przeszkolenia osób w celu w celu stworzenia } \\
\text { bieżącej rezerwy kadrowej }\end{array}$ \\
\hline & prawne & $\begin{array}{l}\text { w przypadku wątpliwości w interpretacji poszczególnych } \\
\text { przepisów należy w większym stopniu wykorzystywać } \\
\text { wiedzę i doświadczenie Zespołu Radców Prawnych }\end{array}$ \\
\hline & techniczne & $\begin{array}{l}\text { rekomenduje się dokonanie przeglądu funkcjonowania } \\
\text { zasobów sprzętowych: pojazdów, sprzętu łączności, } \\
\text { uzbrojenia, kamizelek, ochraniaczy, zestawów sprzętowych) } \\
\text { niezbędnych do prawidłowego wykonywania zadań }\end{array}$ \\
\hline & nadzorcze & $\begin{array}{l}\text { należy dokonać analizy stosownych zasad zarządzania, } \\
\text { kontroli oraz powierzania mienia; należy wprowadzić } \\
\text { szczegółowe odpowiedzialności za poszczególne podoperacje } \\
\text { i zadania odcinkowe dla zabezpieczenia imprezy }\end{array}$ \\
\hline
\end{tabular}

Źródło: opracowanie własne.

Na podstawie analizy ryzyka audytor wewnętrzny dokonuje ukierunkowania zakresu i szczegółowości czynności doradczych. 


\section{Obszary oceny działań $w$ ramach czynności doradczych}

Specyfika realizacji czynności doradczych audytu wewnętrznego dotyczy przeglądu wdrażanych działań w obszarach zidentyfikowanych rodzajów ryzyka oraz transferu ryzyka w obszarach odpowiedzialności.

Punktem wyjścia do oceny zagadnienia były stany zdefiniowane na etapie przeglądu wstępnego oraz analizy bieżącej obszaru wskazującego następujące elementy:

a) identyfikację przekazania wiedzy z zakresu imprezy określnej przez organizatora;

b) dostępne siły i środki policyjne i pozapolicyjne podczas trwania imprezy;

c) utrudnienia na trasach dojazdowych do Szczecina w ruchu drogowym;

d) duże skupiska ludzi i jednostek pływających;

e) niedrożność dróg ewakuacyjnych, zwłaszcza w trakcie koncertów, kiedy nie ma możliwości przedostania się służb policyjnych, np. z góry na dół na Wałach Chrobrego;

f) udział Prezydenta RP oraz innych osób podlegających ochronie BOR, ze względu na prawdopodobną zmianę procedur ochrony;

g) zaginięcia osób, głównie nieletnich;

h) możliwość odbywania się w tym samym czasie innych imprez masowych, sportowych oraz artystyczno-rozrywkowych;

i) obecność na terenie Szczecina osób różnych narodowości (uchodźcy, załogi statków), a w efekcie większe zagrożenie zamachem terrorystycznym;

j) utrudnienia w ruchu wodnym;

k) rozboje, kradzieże, uszkodzenia ciała;

1) możliwość wystąpienia utonięć i podtopień;

m) duża liczba osób zwiedzających żaglowce i możliwość przypadkowego wpadnięcia do akwenu wodnego pojedynczych osób z powodu tłumu napierających ludzi w rejonach brzegowych;

n) nieprawidłowe cumowanie jednostek pływających oraz kolizje, blokady toru wodnego;

o) awarie techniczne, np. brak prądu;

p) możliwość niekontrolowanego upadku statku powietrznego (drona) na skupisko ludzi, w związku z czym przestrzeń powietrzna na wniosek policji zostanie zamknięta;

q) zamach terrorystyczny.

\section{Uwagi końcowe}

Czynności doradcze znajdują coraz większe uznanie w ramach funkcjonowania audytu wewnętrznego. Podstawowym zadaniem czynności doradczych jest ograniczenie ryzyka i jego transfer w zakresie bieżącego zarządzania organizacją przez kierownika jednostki.

Działania o charakterze doradczym obejmują w szczególności bieżącą ocenę planowanych działań, projektowanych systemów, procedur i rozwiązań, opiniowanie projektów 
aktów wewnętrznych oraz składanie wniosków i mają na celu usprawnienie funkcjonowania jednostki.

Zrealizowane czynności doradcze w ramach przygotowania do zabezpieczenia imprezy The Tall Ship Races 2017 pozwoliły na identyfikację ryzyka i zaproponowanie jego transferu w odniesieniu do rekomendowanych działań przeznaczonych do wdrożenia kierownikom komórek organizacyjnych policji odpowiadających za realizację zadań w następujących obszarach:

a) funkcji prewencyjnych, których celem jest ochrona bezpieczeństwa i porządku publicznego realizowanego przede wszystkim przez ograniczenie przestrzeni do popełniania przestępstw i wykroczeń;

b) funkcji kryminalnych, których celem jest ściganie sprawców przestępstw popełnionych;

c) funkcji wspomagających, których celem jest zapewnienie warunków finansowych, technicznych i organizacyjnych niezbędnych do realizacji funkcji prewencyjnych i kryminalnych.

\title{
Literatura
}

https://na.theiia.org/Pages/IIAHome.aspx.

http://pl.wikipedia.org.

Komunikat nr 23 Ministra Finansów z dnia 16 grudnia 2009 roku w sprawie standardów kontroli zarządczej dla sektora finansów publicznych (Dz. Urz. Min. Fin., nr 15, poz. 84).

Ustawa z dnia 6 kwietnia 1990 r. o Policji (Dz.U. 2011, nr 287, poz. 1687 z późn. zm.).

Ustawa z dnia 27 sierpnia 2009 r. o finansach publicznych (t.j. Dz.U. 2016, poz. 1870 z późn.zm.).

Winiarska, K. (2005). Teoretyczne i praktyczne aspekty audytu wewnętrznego. Warszawa: Difin.

\section{ADVISORY FUNCTIONS OF INTERNAL AUDIT IN THE POLICE IN THE AREA OF SECURITY OF THE RACE FINALE OF "THE TALL SHIP RACES 2017"}

\begin{abstract}
Purpose - Implementation of advisory service of internal audit in the area of the Police preparation to secure the race finale of "The Tall Ship Races 2017".

Design/methodology/approach - The risk map method in internal audit was used in order to identify needs and diagnose risk on the basis of the data collected from management and people chosen to secure participants of special events.

Findings - On the basis of the analysis, conducted with the risk map, information about potential risk type and their influence on the organization of security of a mass event was obtained.

Originality/value - The research material allowed to investigate the issue objectively and independently and make a conclusion about the implementation of advisory service.
\end{abstract}

Keywords: internal audit, advisory services, risk, mass event

\section{Cytowanie}

Jasztal, M. (2017). Funkcje doradcze audytu wewnętrznego w policji w zakresie zabezpieczenie finału regat The Tall Ship Races 2017. Finanse, Rynki Finansowe, Ubezpieczenia, 3 (87/1) s. 9-18. DOI: 10.18276/ frfu.2017.87/1-01. 